Bangladesh J. Plant Taxon. 24(2): 149-154, 2017 (December)

(C) 2017 Bangladesh Association of Plant Taxonomists

\title{
GENETIC VARIATION AND MOLECULAR RELATIONSHIPS AMONG EIGHT TAXA OF DESMODIUM DESV. BASED ON RAPD MARKERS
}

\author{
M. Oliur Rahman ${ }^{1}$, Md. Zahidur Rahman, Sonia Khan SONY ${ }^{2}$ \\ AND MOHAMMAD NuRUL ISLAM \\ Department of Botany, University of Dhaka, Dhaka-1000, Bangladesh
}

Keywords: Desmodium Desv.; RAPD; Genetic diversity; UPGMA; Bangladesh.

\begin{abstract}
Genetic variation and molecular relationships among eight taxa of Desmodium Desv. were assessed on the basis of random amplified polymorphic DNA (RAPD) markers. The banding patterns of eight taxa namely, Desmodium gangeticum (L.) DC., D. heterocarpon (L.) DC., D. heterophyllum (Willd.) DC., D. motorium (Houtt.) Merr., D. pulchellum (L.) Benth., D. triflorum (L.) DC., D. triquetrum (L.) DC. and D. triquetrum subsp. alatum (DC.) Prain were compared. A total of 81 DNA fragments were detected by 11 primers. Among the taxa studied $D$. triquetrum and $D$. triquetrum subsp. alatum were found to be most closely related followed by close proximity between $D$. gangeticum and $D$. motorium. The highest genetic distance was observed between $D$. triflorum and $D$. heterophyllum followed by $D$. heterocarpon and $D$. heterophyllum. UPGMA dendrogram was constructed to show the genetic relatedness among the taxa employed and the tree revealed a close proximity among $D$. pulchellum, D. gangeticum and $D$. motorium. In contrast, $D$. heterophyllum was found distantly related with rest of the taxa.
\end{abstract}

\section{Introduction}

Desmodium Desv. belongs to the family Fabaceae comprises about 280 species widespread in the tropical and subtropical regions (Puhua and Ohashi, 2010). In Bangladesh Desmodium is represented by 19 taxa (Ahmed et al., 2009). They are annual to perennial herbs, undershrubs or shrubs, and characterized by possessing uni- or tri-foliolate leaves, simple raceme or panicle inflorescence and distinctly jointed pods. The systematics of the genus Desmodium is confusing and not yet resolved completely (Ohashi and Mill, 2000). Several taxonomic studies on Desmodium were carried out based on morphology and anatomy (Pedley and Rudd, 1996; Shaheeen, 2008; Puhua and Ohashi, 2010). Recently, Rahman and Rahman (2012) conducted a morphometric study of Desmodium and showed interspecific relationships among 14 species of the genus. However, molecular studies employing different DNA markers on this genus are very scanty (Yue et al., 2010; Ahmad Haji et al., 2016).

Recent progress in DNA marker technology have augmented the marker resources for genetic analyses of a wide variety of genomes. The development of random amplified polymorphic DNA (RAPD) markers generated by polymerase chain reaction (PCR) using arbitrary primers has resulted in alternative molecular markers for the detection of nuclear DNA polymorphism (Williams et al., 1990). RAPD markers have application in many fields including DNA fingerprinting (Elavazhagan et al., 2009), assessment of genetic diversity (Bodo Slotta and Porter, 2006), cultivar identification (Sipahi et al., 2010), estimation of population genetics (Sales et al.,

\footnotetext{
${ }^{1}$ Corresponding author. Email: prof.oliurrahman@gmail.com

${ }^{2}$ Department of Botany, University of Barisal, Barisal 8200, Bangladesh
} 
2001), hybridization (Caraway et al., 2001), systematics (Vilatersana et al., 2005), phylogeny reconstruction (Ahmed et al., 2005), and genome mapping (Krutovaskii et al., 1998).

In legume species, RAPD markers have proven to be a useful tool in studies analyzing genetic variation (Yamaguchi and Jabadi, 2004; Bisoyi et al., 2010). Previous studies on Desmodium using isozymes were conducted mainly with species which are important as forage (Smith and Schaal, 1979; Imrie and Blogg, 1983). Application of RAPD markers for detecting genetic variation and interspecific relationships of Desmodium is very limited. Bedolla-Garcia and LaraCabrera (2006) applied RAPD markers to detect genetic variation within and among five population of Desmodium sumichrastii from Mexico. Very recently, Singh et al. (2016) employed RAPD analysis for DNA fingerprinting of only two species of Desmodium, viz., D. gangeticum and D. laxiflorum. However, no detailed study based on RAPD markers for detecting genetic diversity and interspecific relationships in Desmodium was carried out so far. Therefore, the aims of the present study are two-fold: i) to detect the genetic diversity among eight Desmodium taxa, and ii) to infer the relationship among these taxa of Desmodium based on RAPD analysis.

\section{Materials and Methods}

\section{Plant materials}

Eight taxa of Desmodium were collected from different places of Bangladesh, viz., Desmodium gangeticum (L.) DC., D. heterocarpon (L.) DC., D. heterophyllum (Willd.) DC., D. motorium (Houtt.) Merr., D. pulchellum (L.) Benth., D. triflorum (L.) DC., D. triquetrum (L.) DC. and D. triquetrum subsp. alatum (DC.) Prain (Table 1). Leaf samples were used for DNA isolation and were preserved at $-80^{\circ} \mathrm{C}$ until further use. The voucher specimens are deposited at Dhaka University Salar Khan Herbarium (DUSH).

Table 1. List of Desmodium Desv. taxa used for RAPD analysis.

\begin{tabular}{|c|c|c|c|}
\hline No. & Taxa & Habit & Voucher specimens \\
\hline 1. & $\begin{array}{l}\text { Desmodium gangeticum } \\
\text { (L.) DC. }\end{array}$ & Undershrub & $\begin{array}{l}\text { Dhaka: 27.9.2011, Zahid } 85 \text { (DUSH); Munshigonj: } \\
\text { 1.1.2011, Zahid } 7 \text { (DUSH). }\end{array}$ \\
\hline 2. & D. heterocarpon (L.) DC. & Undershrub & $\begin{array}{l}\text { Cox's Bazar: Teknaf, 24.4.2011, Zahid } 28 \text { (DUSH); } \\
\text { Gazipur: Rajendrapur, 5.11.2011, Zahid 91(DUSH). }\end{array}$ \\
\hline 3. & $\begin{array}{l}\text { D. heterophyllum (Willd.) } \\
\text { DC. }\end{array}$ & Herb & $\begin{array}{l}\text { Gazipur: Rajendrapur, 15.7.2011, Zahid } 50 \text { (DUSH); } \\
\text { Cox's Bazar: Pekua, 21.8.2011, Zahid } 74 \text { (DUSH). }\end{array}$ \\
\hline 4. & D. motorium (Houtt.) Merr. & Undershrub & Dhaka: 23.12.2010, Zahid 02 (DUSH). \\
\hline 5. & D. pulchellum (L.) Benth. & Shrub & Gazipur: Rajendrapur, 15.7.2011, Zahid 48 (DUSH). \\
\hline 6. & D. triflorum (L.) DC. & Herb & $\begin{array}{l}\text { Cox's Bazar: Kutubdia island, 17.7.2011, Zahid } 63 \\
\text { (DUSH); Narsingdi: Wari Boteshwar, 10.11.2011, } \\
\text { Zahid } 96 \text { (DUSH). }\end{array}$ \\
\hline 7. & D. triquetrum (L.) DC. & Shrub & Cox’s Bazar: Teknaf, 24.4.2011, Zahid 31(DUSH). \\
\hline 8. & $\begin{array}{l}\text { D. triquetrum subsp. } \\
\text { alatum (DC.) Prain }\end{array}$ & Shrub & Cox's Bazar: Teknaf, 19.7.2011, Zahid 73 (DUSH). \\
\hline
\end{tabular}

\section{Genomic DNA isolation}

DNA was isolated from leaves using the CTAB (Cetyl trimethyl ammonium bromide) method following Doyle and Doyle (1987). The isolated DNA was preserved in TE buffer and stored at $-20^{\circ} \mathrm{C}$. 


\section{RAPD amplification}

The oligonucleotide primers tested for RAPD analysis were presented in Table 2. These primers were chosen by their number and consistency of amplified fragments for analyzing Desmodium taxa. The amplification reaction contained $50 \mathrm{ng}$ of genomic DNA, 0.5 unit of Taq DNA polymerase, $0.5 \mu \mathrm{l}$ of each dNTPs, $10 \mathrm{mM} \mathrm{MgCl} 2,1 \mu 1$ decamer random primers (Operon Biotechnology, Germany) and $2.5 \mu \mathrm{l} 10 \mathrm{X}$ amplification buffer in a total volume of $25 \mu \mathrm{l}$. The amplifications were performed in triplicate using PCR thermal cycler (Biometra UNOII, Germany) with initial denaturation of $5 \mathrm{~min}$ at $94^{\circ} \mathrm{C}$, followed by 42 cycles at $94^{\circ} \mathrm{C}$ for $5 \mathrm{sec}$, $33^{\circ} \mathrm{C}$ for $1 \mathrm{~min}$ and $72^{\circ} \mathrm{C}$ for 2 min with final extension of $5 \mathrm{~min}$ at $72^{\circ} \mathrm{C}$. The amplified products were separated on $1 \%$ agarose gel containing ethidium bromide, and photographed under UV light.

Table 2. List of primers used in RAPD analysis.

\begin{tabular}{llc}
\hline Primer Code & Sequence $\left(5^{\prime}-3^{\prime}\right)$ & $\mathrm{G}+\mathrm{C}$ content $(\%)$ \\
\hline OPA-1 & TGCCGAGCTC & 70 \\
OPA-2 & TGCCGAGCTG & 70 \\
OPA-3 & AGTCAGCCAC & 60 \\
OPA-6 & GGTCCCTGAC & 70 \\
OPA-7 & GAAACGGGTG & 60 \\
OPA-8 & GTGACGTAGG & 60 \\
OPA-9 & GTGATCGCAG & 60 \\
OPA-10 & GTGATCGCAG & 60 \\
A15 & TTCCGAACCC & 60 \\
B14 & TCCGCTCTGG & 70 \\
BO6 & TGCTCTGCCC & 70 \\
\hline
\end{tabular}

Data analysis

RAPD bands were recorded in a binary data matrix scored as presence (1) or absence (0). The score obtained using all primers in the RAPD analysis were then combined to create a single data matrix. The size of amplification products were estimated by comparing the migration of each amplified fragments with that of a known size fragments of $1 \mathrm{~kb}$ molecular weight marker. Genetic linkage distance was determined using the data matrix. UPGMA (Unweighted pair group method with arithmetic means) dendrogram was constructed to show the genetic relationships among the species (Sneath and Sokal, 1973). All analyses were performed using the Statistica program.

\section{Results and Discussion}

A total of 81 RAPD bands were scored with eleven RAPD primers in eight Desmodium taxa. The highest number of fragments was detected in Desmodium heterophyllum (31) followed by $D$. triflorum (20) and D. heterocarpon (7), while the lowest band observed in D. motorium (1). The highest number of fingerprints were generated by the primer OPA- 8 and least number in OPA-1.

The RAPD markers have been found efficient to detect genetic variation in Desmodium. The highest dissimilarity (41.0) was observed between $D$. triflorum and $D$. heterophyllum followed by D. pulchellum and D. heterophyllum (35.5) and D. heterophyllum and D. heterocarpon (35.0) (Table 3). The lowest genetic distance (1.0) was found between D. gangeticum and D. motorium indicating that these species are very closely related (Table 3 ). 
Cluster analysis of the genetic similarity estimates from RAPD markers was performed to generate the UPGMA dendrogram for showing genetic relationship among the taxa of Desmodium (Fig. 1). The dendrogram revealed that $D$. pulchellum, D. gangeticum, D. motorium, $D$. triquetrum, $D$. triquetrum subsp. alatum, and $D$. heterocarpon grouped together and formed a cluster showing a close relationships among them. This cluster further consisted of two subclusters, the first one contained $D$. pulchellum, D. gangeticum and $D$. motorium showing a close affinity between these three species, while the second sub-cluster comprised $D$. triquetrum subsp. alatum, $D$. triquetrum, and $D$. heterocarpon. The highest relatedness was observed between $D$. gangeticum and D. motorium among all the taxa employed in this study. The RAPD analysisalso shown that $D$. heterophyllum and $D$. triflorum retained ungrouped and they are distantly related from other taxa of Desmodium.

Table 3. Genetic variation among studied taxa of Desmodium.

\begin{tabular}{|c|c|c|c|c|c|c|c|c|}
\hline Taxa & $\begin{array}{l}\text { D. pulche- } \\
\text { llum }\end{array}$ & $\begin{array}{l}\text { D. triflo- } \\
\text { rum }\end{array}$ & $\begin{array}{c}\text { D. hetero- } \\
\text { carpon }\end{array}$ & $\begin{array}{c}\text { D. hetero- } \\
\text { phyllum }\end{array}$ & $\begin{array}{l}\text { D. triquetrum } \\
\text { subsp. alatum }\end{array}$ & $\begin{array}{l}\text { D. trique- } \\
\text { trum }\end{array}$ & $\begin{array}{l}\text { D. gange- } \\
\text { ticum }\end{array}$ & $\begin{array}{l}\text { D. moto- } \\
\text { rium }\end{array}$ \\
\hline D. pulchellum & 0 & & & & & & & \\
\hline D. triflorum & 28.3 & 0 & & & & & & \\
\hline D. heterocarpon & 14.1 & 32.2 & 0 & & & & & \\
\hline D. heterophyllum & 35.5 & 41.0 & 35.0 & 0 & & & & \\
\hline $\begin{array}{l}\text { D. triquetrum } \\
\text { subsp. alatum }\end{array}$ & 8.0 & 26.3 & 14.1 & 33.5 & 0 & & & \\
\hline D. triquetrum & 8.0 & 26.3 & 12.1 & 33.5 & 8.0 & 0 & & \\
\hline D. gangeticum & 6.0 & 24.3 & 12.1 & 33.6 & 6.0 & 6.0 & 0 & \\
\hline D. motorium & 5.0 & 25.4 & 11.1 & 32.6 & 5.0 & 5.0 & 1.0 & 0 \\
\hline
\end{tabular}

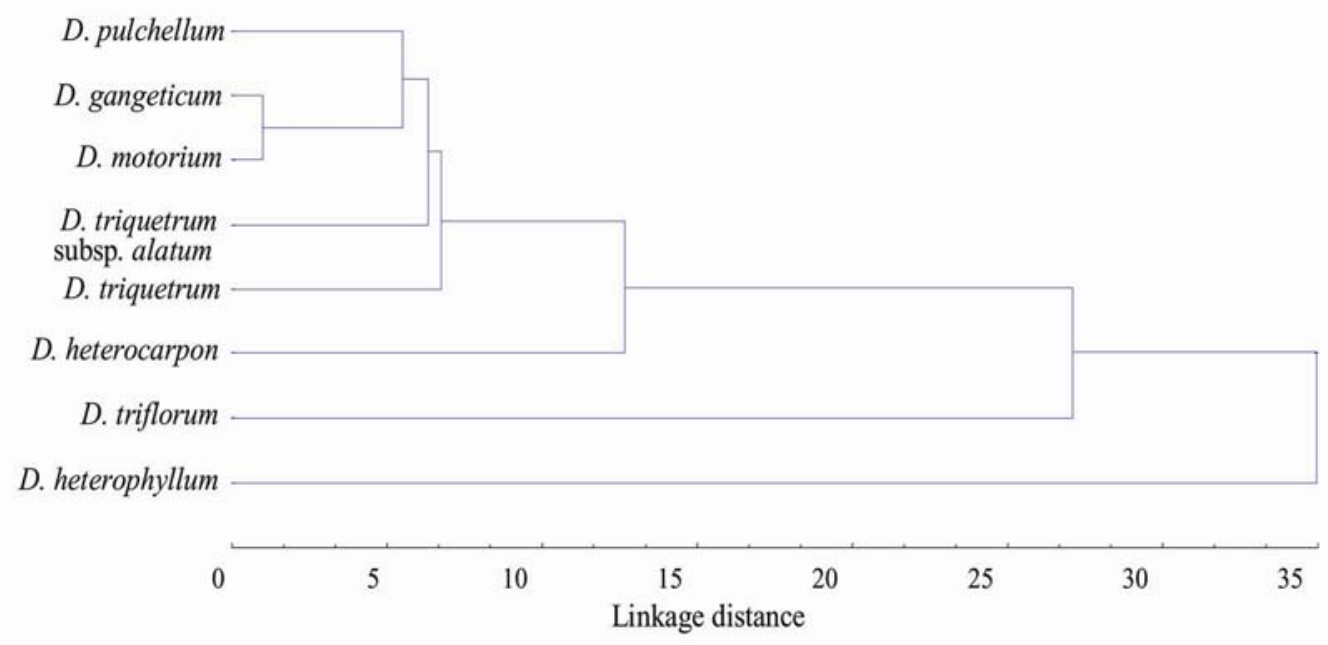

Fig. 1. UPGMA dendrogram showing the genetic relationship among studied Desmodium taxa based on RAPD markers. 
The RAPD method is popular because of its technical simplicity and speed. The present study reveals that RAPDs are useful markers in identifying Desmodium species. The RAPD data shows that $D$. gangeticum and $D$. motorium are genetically closely related. This result is congruent with the previous study based on morphological characters such as unifoliolate, lanceolate leaves and triangular stipules (Ahmed et al., 2009); and also supported by foliar anatomical investigation (data not shown). Bedolla-Garcia and Lara-Cabrera (2006) studied genetic variation within and among five populations of Desmodium sumichrastii from Mexico based on RAPD analysis. Singh et al. (2016) employed RAPD approach for the genetic fingerprinting of Desmodium gangeticum and D. laxiflorum and found $60-65 \%$ similarity between these two species. Irshad et al. (2009) studied three species of Desmodium, viz. D. gangeticum, D. triflorum and $D$. velutinum (Willd.) DC. and compared with commercial samples of various origin. Among these $D$. triflorum appears closer to $D$. gangeticum reflecting narrow genetic diversity. However, the present study shows that $D$. triflorum and $D$. gangeticum are distantly related. Very recently, Malgaonkar et al. (2016) determined the genetic relatedness and diversity among accessions of four Desmodium species using RAPD markers, namely D. dichotomum (Willd.) DC., D. laxiflorum DC., D. scorpiurus (SW.) Poir. and D. triflorum. A close affinity has been observed between $D$. laxiflorum and D. scorpiurus. In the present study D. pulchellum has been found close to $D$. gangeticum and D. motorium indicating that these three species are closely related. D. triflorum and $D$. heterophyllum are closely allied as evidenced by anatomical study (Data not shown), however, this affinity is not supported by RAPD analysis. In order to have better understanding about genetic relatedness and interspecific relationships inclusion of more taxa with additional markers is necessary.

\section{Acknowledgements}

The first author gratefully acknowledges the financial assistance provided by the Biotechnology Research Centre of the University of Dhaka for carrying out the research. The authors are grateful to Prof. Rakha Hari Sarkar and Prof. Md. Imdadul Hoque, Department of Botany, University of Dhaka for their cooperation during the course of the study. Thanks are also due to Dr. Sujay Kumar Bhajan of the Department of Botany, University of Dhaka for his help and cooperation.

\section{References}

Ahmad Haji, R.F., Tiwari, S., Gandhi, S.G., Kumar, A., Brindavanam, N.B. and Verma, V. 2016. Genetic diversity analysis among accessions of Desmodium gangeticum (L.) DC. with simple sequence repeat (SSR) and internal transcribed spacer (ITS) regions for species conservation. J. Biodivers. Biopros. Dev. 3: 159 .

Ahmed, S.M., Verma, V., Qazi, P.H., Ganaie, M.M., Bakshi, S.K. and Qazi, G.N. 2005. Molecular phylogeny in Indian Tinospora species by DNA based molecular markers. Plant Syst. Evol. 256(1-4): $75-87$.

Ahmed, Z.U., Hassan, M.A., Begum, Z.N.T. Khondoker, M., Kabir, S.M.H., Ahmed, M., Ahmed, A.T.A., Rahman, A.K.A. and Haque, E.U. (Eds) 2009. Encyclopedia of Flora and Fauna of Bangladesh, Vol. 8. Angiosperms: Dicotyledons (Fabaceae - Lythraceae). Asiatic Society of Bangladesh, Dhaka. pp. 1-478.

Bedolla-Garcia, B.Y. and Lara-Cabrera, S.I. 2006. An assessment of genetic diversity in Desmodium sumichrastii (Fabaceae) in Mexico. Can. J. Bot. 84: 876-882.

Bisoyi, M.K., Acharya, L., Mukherjee, A.K. and Panda, P.C. 2010. Study of inter-specific relationship in six species of Sesbania Scop. (Leguminosae) through RAPD and ISSR markers. International J. Plant Physiol. \& Biochem. 2(2): 11-17. 
Bodo Slotta, T.A. and Porter, D.M. 2006. Genetic variation within and between Iliamna corei and I. remota (Malvaceae): implication for species delimitation. Bot. J. Linn. Soc. 151: 345-354.

Caraway, V., Carr, G.D. and Morden, C.W. 2001. Assessment of hybridization and introgession in lava colonizing Hawaiian Dubautia (Asteraceae: Madiinae) using RAPD markers. Am. J. Bot. 88: 16881694.

Doyle, J.J. and Doyle, J.L. 1987. A rapid DNA isolation procedure for small quantities of fresh leaf tissue. Phytochem. Bull. 19: 11-15.

Elavazhagan, T., Ramakrishnan, M., Jayakumar, S., Chitravadivu, C. and Balakrishnan, V. 2009. Fingerprinting analysis in Casurina equisetifolia by using RAPD markers. Botany Res. Int. 2(4): 244-247.

Imrie, B.C. and Blogg, D. 1983. Variability in isozyme gene frequency in the tropical pasture legumes, 'Greenleaf' Desmodium. Trop. Agric. 60: 193-196.

Irshad, S., Singh, J., Kakkar, P. and Mehrotra, S. 2009. Molecular characterization of Desmodium species An important ingredient of 'Dashmoola' by RAPD analysis. Fitoterapia 80: 115-118.

Krutovskii, K.V., Vollmer, S.S., Sorensen, F.C., Adams, W.T., Knapp, S.J. and Strauss, S.H. 1998. RAPD genome map of Douglas-fir. J. Heredity 89: 197-207.

Malgaonkar, M., Murthy, S.N. and. Pawar, S.D. 2016. Molecular analysis and study of genetic relationships among species of Desmodium Desv. using RAPD markers. J. Adv. Biol. \& Biotech. 6(4): 1-7.

Ohashi, H. and Mill, R.R. 2000. Hylodesmum, a new name for Podocarpium (Leguminosae). Edinburgh J. Bot. 57: 171-188.

Pedley, L. and Rudd, V.E. 1996. Fabaceae, Tribe Desmodieae. In: Dassanayake, M.D. and Clayton, W.D. (Eds), Flora of Ceylon. Vol. 10. Oxford \& IBH publishing Co. Pvt. Ltd., New Delhi. pp. 149-198.

Puhua, H. and Ohashi, H. 2010. Desmodium Desv. In: Wu, Z.Y., Raven, P.H. and Hong, D.Y. (Eds), Flora of China. Vol. 10 (Fabaceae). Science Press, Beijing, and Missouri Botanical Garden Press, St. Louis. pp. 268-278.

Rahman, M.Z. and Rahman, M.O. 2012. Morphometric analysis of Desmodium Desv. (Fabaceae) in Bangladesh. Bangladesh J. Bot. 41(2): 143-148.

Sales, E., Nebauer, S.G., Mus, M. and Segura, J. 2001. Population genetics study in the Balearic endemic plant species Digitalis minor (Scrophulariaceae) using RAPD markers. Am. J. Bot. 88: 1750-1759.

Shaheen, A.S.M. 2008. Morphological and anatomical investigation in Desmodium tortuosum (SW.) DC. (Fabaceae): A new addition to the Egyptian flora. Bangladesh J. Plant Taxon. 15(1): 21-29.

Singh, S., Harisha C.R., Goyal, M. and Patel, B.R. 2016. Comparative molecular characterization of Desmodium gangeticum DC. and Desmodium laxiflorum DC. through random amplified polymorphic DNA (RAPD) analysis. Asian J. Plant Sci. \& Res. 6(1): 22-26.

Sipahi, H., Akar, T., Yildiz, M.A. and Sayim, I. 2010. Determination of genetic variation and relationship in Turkish Barley cultivars by hordein and RAPD markers. Turkish J. Field Crops 15(2): 108-113.

Smith, W.G. and Schaal, B.A. 1979. Isozme variation in Desmodium nudiflorum. Biochem. Syst. Ecol. 7: 121-123.

Sneath, P.H.A. and. Sokal, R.R. 1973. Numerical Taxonomy. Freeman and Company, San Francisco. 573 pp.

Vilatersana, R., Garnatje, T., Susanna, A. and Garcia-Jacas, N. 2005. Taxonomic problems in Carthamus (Asteraceae): RAPD markers and sectional classification. Bot. J. Linn. Soc. 147: 375-383.

Williams, J.G.K., Kubelik, A.R., Livak, K.J., Rafalski, J.A. and Tingey, S.V. 1990. DNA polymorphisms amplified by arbitrary primers are useful as genetic markers. Nucleic Acids. Res. 18: 176-183.

Yamaguchi, H. and Jabadi, F. 2004. RAPD and seed coat morphology variation in annual and perennial species of the genus Cicer L. Plant Genet. Res. Crop Evol. 51: 783-794.

Yue, M.-F., Zhou, R.-C., Huang, Y.-L., Xin, G.-R., Shi, S.-H. and Feng, L. 2010. Genetic diversity and geographical differentiation of Desmodium triflorum (L.) DC. in south China revealed by AFLP markers. J. Plant Biol. 53: 165-171. 